\author{
Adam ADAMCZYK, PhD, Professor US \\ Faculty of Economics Finance and Management, University of Szczecin \\ e-mail: adam.adamczyk@usz.edu.pl \\ ORCID: 0000-0002-0491-5502
}

DOI: $10.15290 /$ oes.2020.04.102.02

\title{
MACRO DETERMINANTS OF THE INCOME UNDERREPORTING BY THE SELF-EMPLOYED ${ }^{1}$
}

\begin{abstract}
Summary
Purpose - The aim of the article is to indicate the macro factors shaping the phenomenon of concealing income by self-employed workers.

Research method - This article uses the comparative analysis method together with an analysis of critical literature. The empirical element employs dependency analysis methods.

Results - The conducted analyses indicate the lack of a relationship between the level of economic development of the state and the scale of the phenomenon of income concealment. Similarly, it has been demonstrated that there is no evidence of a correlation between the level of unemployment and the rate of self-employment and the scale of income concealment by self-employed people. The results of the conducted analyses allowed the identification of two paradoxes. The first consists in the existence of a negative relationship between the scale of income concealment and the size of the grey economy, while the second consists in the occurrence of a positive relationship between the friendliness of the tax system for entrepreneurs and the scale of lowering the tax base.

Originality / value / implications / recommendations - The article supplements an existing research gap. The research undertaken thus far concerned the analysis of factors influencing the international diversity of the grey sphere size. However, no detailed analysis was carried out regarding the impact of macro factors on the shaping of the grey economy, including the lowering of incomes by self-employed workers. The original contribution of the article is also the study of the relationship between the size of the phenomenon of income understatement and the size of the grey economy.
\end{abstract}

Keywords: self-employment, income underreporting, taxation

JEL Classification: J38, J08, H30, L53

\section{Introduction}

Self-employment is frequently considered as a positive economic phenomenon that is conducive to innovation and combats unemployment. However, it is also connected with such adverse effects as the increased importance of precariat and consequently with employment instability. Income uncertainty of self-employed workers results in lifetime decisions concerning starting a family and having

1 Article received on 17 April 2020, accepted on 29 May 2020. 
children. The increase in the levels of self-employment may also have adverse effects as regards to taxation. As research shows [Jacobsen Kleven et al., 2011], it is particularly in relation to self-employment that the concealment of tax incomes occurs in a group of workers on civil law contracts. Furthermore, the possibility to either avoid or considerably reduce taxation is mentioned as one of the motives for changing the form of employment into self-employment [Blau, 1987; Parker, 1996; Robson, Wren, 1999; Bruce, 2000; Schuetze, 2000]. The concealment of income by self-employed workers causes the erosion of the tax base and thus also causes a reduction in the achieved tax incomes. At the same time, the differentiation in the level of tax burdens between the employed and self-employed workers (resulting from the non-taxation of some incomes of self-employed workers) distorts the functioning of the market mechanism on the labour market. In attempting to reduce the phenomenon of reducing tax incomes by self-employed workers it is necessary to recognise the reasons that cause them and to specify the conditions that are conducive to the development of this phenomenon. The aim of this paper is an attempt to answer the question as to which factors of the macro surrounding may have influence on the scale of the phenomenon related to the concealment of incomes by self-employed workers. In order to analyse this, it is necessary to use data regarding the estimates of the method incomes are lowered in particular countries. To achieve this objective, data combined with the results of the latest research on the estimation of income lowering by self-employed workers that was conducted for fourteen EU states by Kukk et al. [2019] are utilised. The estimates related to the lowering of tax incomes were then juxtaposed with the basic characteristics describing the countries analysed in the research.

\section{The essence of the income concealment}

The analysis of the factors shaping income concealment ought to be preceded by a precise definition of this concept. It results from the fact that this notion may be associated with similar concepts such as grey economy or tax fraud. However, it should be stressed that these concepts are identical. It means that the phenomena defined while using them may have various reasons and effects. The diversification of these categories makes it necessary to use various approaches in measuring them.

Grey area is the category with the broadest scope of meaning. However, this concept is not defined explicitly. One of these meanings indicates all the unregistered types of economic activity that contribute to the creation of officially calculated (or observed) gross national product [Schneider, Klinglmair, 2004]. Such a definition of grey area implies that it includes only the unregistered activity. The definitions created subsequently have formulated this concept in a broader way as an economic activity (and the income accruing from it) which evades the government regulation, taxation or observation [Del'Anno, 2003]. Hence, during the specification of the scope of meaning of grey area one may assume that it is composed of three elements [Lapiński et al., 2014]: 
- illegal activity;

- $\quad$ hidden activity - mainly income lowering in the companies functioning in a legal way;

- informal activity - mainly connected with unregistered work.

Tax evasion in terms of meaning as a concept is narrower than grey area. According to Sandomo [2005] this term means "the violation of the tax law and, in particular, the situation where a taxpayer abstains from the disclosure of income from work or capital which, in principle, is subject to tax, gets involved in an illegal activity which exposes them to administrative or legal activities undertaken by authorities". On the basis of the aforementioned definition it can be concluded that its author associates to a great extent the phenomenon of tax evasion with the concept of tax income concealment. A similar conclusion may be drawn by analysing the definitions formulated by international institutions. According to the OECD, tax evasion means illegal activities, as the result of which a taxpayer pays less tax than it is necessary by means of concealing income or information from tax administration [www 1]. Although these two definitions clearly emphasise the fact that income underreporting constitutes the main form of tax evasion, these concepts are not entirely considered as the identical ones. In the first definition, one form of tax evasion is some unspecified illegal activity which may expose a taxpayer to the sanctions from the state. The second definition shows that tax evasion may also entail the concealment of information from tax administration. Therefore, both definitions leave certain room where tax evasion includes also activities that are not only connected with income concealment.

TABLE 1

The taxonomy of the types of untaxed activities

\begin{tabular}{|l|l|l|l|l|}
\hline $\begin{array}{l}\text { Type of } \\
\text { activity }\end{array}$ & \multicolumn{2}{|c|}{ Monetary transactions } & \multicolumn{2}{|c|}{ Non-monetary transactions } \\
\hline $\begin{array}{l}\text { Illegal } \\
\text { activity }\end{array}$ & $\begin{array}{l}\text { Receiving stolen property, trade and } \\
\text { the production of drugs, prostitution, } \\
\text { gambling, smuggling, fraud, etc. }\end{array}$ & $\begin{array}{l}\text { Barter of drugs, stolen properties, } \\
\text { smuggling. The production of drugs } \\
\text { for personal use, theft for personal use }\end{array}$ \\
\hline $\begin{array}{l}\text { Lawful } \\
\text { activity }\end{array}$ & $\begin{array}{l}\text { Tax evasion } \\
\text { The concealment } \\
\text { of income from } \\
\text { self-employment; } \\
\text { Remunerations and } \\
\text { assets from undeclared } \\
\text { (unregistered) work that } \\
\text { is connected with the } \\
\text { activity that is not } \\
\text { banned by law }\end{array}$ & $\begin{array}{l}\text { The use of } \\
\text { loopholes } \\
\text { in the tax } \\
\text { law }\end{array}$ & $\begin{array}{l}\text { Barter exchange of } \\
\text { legal goods and } \\
\text { services }\end{array}$ & $\begin{array}{l}\text { Tll do it yourself } \\
\text { activities } \\
\text { Work and the } \\
\text { assistance of } \\
\text { a neighbour }\end{array}$ \\
\hline
\end{tabular}

Source: [Schneider, Klinglmair, 2004]. 
The taxonomy of the types of untaxed activity (presented in table 1) [Schneider, Klinglmair, 2004] demonstrates that tax evasion includes not only income concealment, but also the incomes earned from an informal activity.

However, the approach presented in table 1 has limitations as it is based on the assumption that the only form of lowering tax liabilities is to conceal tax revenue. And yet, in reality the illegal reduction of the tax liability may result not only from the concealment of the tax base, but also from the activities connected with the unlawful usage of other elements of tax techniques, such as tax reductions and exemptions. Thus, during the analysis of tax evasion one should state that it comprises all the unlawful activities that are aimed at reducing or removing tax liability completely. To summarise, it can be concluded that tax evasion is one of the phenomena which creates the grey economy, while income concealment is one of the most important forms (but not the only) of tax evasion.

\section{The determinants of tax revenue underreporting in the light of the theory of tax fraud}

Looking for the potential determinants of the phenomenon of concealing tax revenue it is necessary to analyse chiefly the factors that are taken into account in the theories which attempt to explain the taxpayers' inclination to pay taxes. Among the classical theories concerning this problem, are listed the theories on maximising the expected utility used by Alingahm and Sandomo as well as Srinivasan's theory [1973] on maximising the expected income. These theories are based on the neoclassical assumption that each taxpayer is entirely rational. The second group of theories includes the approaches that attempt to explain those behaviours of taxpayers that deny the assumption of their rationality. These theories include the model based on the theory of prospect by Kahneman and Tversky and the model of social interactions.

The theories based on the neoclassical assumption of taxpayers' rationality imply that while making decision on whether to pay taxes or to evade them one compares the expected value of benefits connected with not paying the tax with the expected value of the punishment. In accordance with these theories the inclination to pay taxes may depend on such factors as the nature of the punishment, the probability of punishment, the probability of control (the likelihood of detecting tax fraud), the value of tax rates and the value of gross income.

However, the estimates based on this theory and taking into consideration the fact of low likelihood of punishment or control (usually less than 1\%) frequently lead to the conclusion that most taxpayers should not pay taxes.

The theories from the second group attempt to explain the aforementioned irrational behaviours of taxpayers. In order to determine why taxpayers, pay taxes despite the low probability of control, Dhami and al-Nowaihi [2007] used the theory of perspective. In accordance with the theory of Kahneman and Tversky, people in a subjective way overestimate the objectively low probability and at the same time 
subjectively underestimate the objectively high probability. In accordance with this theory, people pay taxes because they consider tax control to be more probable than it really is. On the other hand, the increase of control probability may not result in the proportional decrease in the scale of tax fraud because in the situation of high probability of control the subjectively sensed level of risk may be lower than the actual level.

Among the theories that explain the irrationality of taxpayers are listed the theories of social interaction. In accordance with these theories, the taxpayers' inclination to pay taxes may depend on the sense of equality (fairness) of taxation. The degree to which tax liabilities are realised in these theories also depends on whether taxpayers may notice the relationship between tax revenues and the supply of public goods. Not without significance is also the way in which taxpayers perceive the activity of the state. Smith and Stalans [1991] indicate that the state's positive activities aimed at the improvement of taxpayers' attitudes are justified. If the state functions in a trustworthy way, taxpayers are more likely to obey tax regulations. There is a rich amount of literature which shows that the inclination to pay taxes is dependent on the tax morality of taxpayers [Frey, Feld, 2002].

While attempting to show the potential determinants of the income lowering, it is possible to refer to empirical research that emphasises the role of risk aversion. There are numerous analyses which prove that the inclination to conceal income may be caused by the factors that determine the taxpayers' aversion to risk, such as sex, age or education level.

\section{Research methodology}

The previous studies of the determinants of the phenomenon of concealing income by self-employed workers were conducted in the macro scale. Their purposes included among others, the identification of socio-economic factors that are conducive to tax evasion. For this purpose, it was necessary to know the scale of income concealment in particular countries. For measuring this phenomenon diverse methodology was employed, including the methods based on the analysis of the consumption of production factors, the value of money supply or data from tax controls. More recent methods make use of the models used by banks in order to specify the actual incomes of the borrowers [Artavanis et al., 2016].

The most popular method of estimating the value of hidden income is the approach offered by Pissarides and Weber [1989]. The scientists dealing with the problem of income concealment by self-employed workers consider this method as "one of the workhorses in the contemporary research on tax fraud". This approach is based on the assumption that the real level of incomes of the self-employed may be specified on the basis of their consumption value. For this purpose, the relationship between consumption and income in the reference group comprising employed people for whom there is estimated the compliance of the actual income achieved with the income shown for tax purposes is used. Such great popularity of 
the P\&W method and the fact that it was designed for estimating income concealment by self-employed workers decided upon using (in further analyses) the results based on this approach.

As it has been emphasised, previous research was focused on the analysis of the impact that micro factors have on the inclination of self-employed workers to pay taxes. However, owing to the insufficiency of comparable research devoted to the lowering of tax incomes on an international scale, there are no analyses of the impact of factors of the macro type. Admittedly, there are analyses that estimate the dimensions of the entire grey area in particular countries [Alm, Embaye, 2013; Tafenau et al., 2010], but on the basis of them it is difficult to isolate the scale of income concealment by self-employed people. Additionally, it is possible to identify the research including the measurement of phenomena having similar character regarding the concealment of income by self-employed such as unregistered work [Hazans, 2011]. A certain breakthrough in this area was the research conducted by Kukk et al. which was published in 2019. While using the unified and corrected method of Pisaredes and Weber, this research determined the scale of income concealment phenomenon in 14 European Union states. Although the number of states analysed in the research is not satisfactory to formulate strict and one-sided conclusions, it is still possible (by analysing data for this group) to provisionally verify the hypotheses connected with the influence of macro factors on the inclination of self-employed workers to conceal income. Among the analysed determinants there are both factors of economic character (such as GDP per capita, the unemployment level or the self-employment rate) and of institutional character, i.e. the corruption level or the quality of the tax system. Owing to the small number of observations in the research, one of the simplest measures of interdependence Pearson correlation coefficient was used.

\section{The analysis of the determinants of income concealment by self-employed workers}

The analysis of factors shaping the scale of the phenomenon of income concealment by self-employed workers will start with the evaluation of the impact of macroeconomic circumstances. The basic volume that characterises the economic condition of the country is the domestic product per capita. The value of this characteristic may constitute not only the basis for the assessment of the economic situation, but also the determinant of the country's development, including the quality of its institutions. Therefore, one may expect that the value of this characteristic ought to be negatively correlated with the scale of tax fraud. Such thesis is also confirmed in the previous research on the relation between the economic development of a state and the dimensions of grey economic area, in accordance with which grey area has negative impact on the rate of economic growth [Schneider, Klinglmair, 2004]. However, the data included in table 2 does not confirm the existence of the expected relationship. 
TABLE 2

\section{The scale of income concealment by self-employed workers versus GDP per capita}

\begin{tabular}{|l|c|c|}
\hline \multicolumn{1}{|c|}{ Country } & $\begin{array}{c}\text { The scale of income concealment } \\
\text { by self-employed workers in \% }\end{array}$ & $\begin{array}{c}\text { GDP } \\
\text { per capita }\end{array}$ \\
\hline Bulgaria & 8.6 & 5790 \\
\hline Cyprus & 9.1 & 21040 \\
\hline Czech Republic & 21.9 & 16160 \\
\hline Estonia & 22 & 13330 \\
\hline Greece & 13.9 & 17080 \\
\hline Spain & 13.5 & 23080 \\
\hline Croatia & 16.8 & 10630 \\
\hline Hungary & 24 & 11130 \\
\hline Ireland & 30.1 & 49470 \\
\hline Lithuania & 25.5 & 11590 \\
\hline Latvia & 35 & 10740 \\
\hline Poland & 13.8 & 10920 \\
\hline Portugal & 10.8 & 16620 \\
\hline Romania & 16.5 & 7320 \\
\hline Pearson correlation coefficient & & 0.26 \\
\hline p-value & & 0.36 \\
\hline
\end{tabular}

Source: own elaboration based on: [Kukk et al., 2019; www 2].

The results obtained point at the occurrence of a positive (but irrelevant in statistic terms) relationship between the analysed values, which is also confirmed in the research conducted by Kukk et al. The results are consistent with the findings of the recent research conducted by D. F. Wu and F. Schneider, according to whom the relation between grey area and GDP per capita adopts the shape of the inverted letter $\mathrm{U}$.

Another analysed dependence is the relation between the phenomenon of income concealment and the unemployment rate. The study of the relationship between these values enables one to expect that a high unemployment level will foster an elevated scale of income concealment. In such circumstances employees are considerably more frequently coerced into self-employment and compensate the inconvenience of this form of employment with the possibility of a more flexible way of shaping the tax base. However, the results obtained (presented in table 3) may not constitute the argument that will confirm such hypothesis as the observed relationship (which is positive) is also irrelevant in statistic terms. 
TABLE 3

\section{The scale of tax underreporting by self-employed workers versus the unemployment rate}

\begin{tabular}{|l|c|c|}
\hline \multicolumn{1}{|c|}{ Country } & $\begin{array}{c}\text { The scale of tax underreporting } \\
\text { by self-employed workers in \% }\end{array}$ & $\begin{array}{c}\text { Unemployment } \\
\text { rate in \% }\end{array}$ \\
\hline Bulgaria & 8.6 & 9.2 \\
\hline Cyprus & 9.1 & 15 \\
\hline Czech Republic & 21.9 & 5.1 \\
\hline Estonia & 22 & 6.2 \\
\hline Greece & 13.9 & 24.9 \\
\hline Spain & 13.5 & 22.1 \\
\hline Croatia & 16.8 & 16.1 \\
\hline Hungary & 24 & 6.8 \\
\hline Ireland & 30.1 & 10 \\
\hline Lithuania & 25.5 & 9.1 \\
\hline Latvia & 35 & 9.9 \\
\hline Poland & 13.8 & 7.5 \\
\hline Portugal & 10.8 & 12.6 \\
\hline Romania & 16.5 & 6.8 \\
\hline Pearson correlation coefficient & & -0.38 \\
\hline p-value & & 0.18 \\
\hline
\end{tabular}

Source: own elaboration based on: [Kukk et al., 2019; www 3].

The lack of the analysed relationship between the unemployment rate and the self-employment rate is reflected in the analysis of the relation between the scale of income concealment and the self-employment rate. The analysis of data included in table 4 indicates that the increase of the self-employment rate does not lead to the increase of income fraction not reported by self-employed workers. On the contrary, the correlation coefficient sign for this relationship indicates that there may occur inverse relationship, which is statistically irrelevant. It may indicate that the employees that are coerced into self-employment are characterised by higher aversion to risk and greater reluctance to tax fraud.

The result of the analysis on the relationship between the income concealment scale and the dimensions of grey area appeared to be quite surprising. Taking into account the fact that income concealment constitutes one of the elements of grey area, the analysed relationship ought to be positive. However, the data presented in table 5 shows that this relationship is not only negative, but also relevant in statistic terms. The only explanation of this paradox may lie in the existence of the negative relationship between the elements of grey area. Assuming that the fraction of people with risk aversion in particular countries is similar, one may expect that in the countries where they may not operate in either unregistered or illegal way, they will work legally and at the same time will try to maximally reduce their tax liabilities. 
TABLE 4

The scale of income concealment by self-employed workers versus the self-employment rate

\begin{tabular}{|l|c|c|}
\hline \multicolumn{1}{|c|}{ Country } & $\begin{array}{c}\text { The scale of income concealment } \\
\text { by self-employed workers in \% }\end{array}$ & $\begin{array}{c}\text { Self-employment rate } \\
\text { in \% }\end{array}$ \\
\hline Bulgaria & 8.6 & 11.90 \\
\hline Cyprus & 9.1 & 13.19 \\
\hline Czech Republic & 21.9 & 17.12 \\
\hline Estonia & 22 & 10.20 \\
\hline Greece & 13.9 & 34.07 \\
\hline Spain & 13.5 & 16.49 \\
\hline Croatia & 16.8 & 12.37 \\
\hline Hungary & 24 & 10.34 \\
\hline Ireland & 30.1 & 15.36 \\
\hline Lithuania & 25.5 & 12.01 \\
\hline Latvia & 35 & 12.66 \\
\hline Poland & 13.8 & 20.42 \\
\hline Portugal & 10.8 & 16.99 \\
\hline Romania & 16.5 & 26.31 \\
\hline Pearson correlation coefficient & & -0.29 \\
\hline p-value & & 0.31 \\
\hline
\end{tabular}

Source: own elaboration based on: [Kukk et al., 2019; www 4].

TABLE 5

The scale of income concealment by self-employed workers versus the dimension of the grey area

\begin{tabular}{|l|c|c|}
\hline \multicolumn{1}{|c|}{ Country } & $\begin{array}{c}\text { The scale of income concealment } \\
\text { by self-employed workers in \% }\end{array}$ & $\begin{array}{c}\text { The dimension of the } \\
\text { grey area as \% GDP }\end{array}$ \\
\hline Bulgaria & 8.6 & 20.83 \\
\hline Cyprus & 9.1 & 32.20 \\
\hline Czech Republic & 21.9 & 10.47 \\
\hline Estonia & 22 & 18.49 \\
\hline Greece & 13.9 & 26.45 \\
\hline Spain & 13.5 & 22.01 \\
\hline Croatia & 16.8 & 22.96 \\
\hline Hungary & 24 & 20.49 \\
\hline Ireland & 30.1 & 9.58 \\
\hline Lithuania & 25.5 & 18.65 \\
\hline Latvia & 35 & 16.62 \\
\hline
\end{tabular}




\begin{tabular}{|l|c|c|}
\hline \multicolumn{1}{|c|}{ Country } & $\begin{array}{c}\text { The scale of income concealment } \\
\text { by self-employed workers in \% }\end{array}$ & $\begin{array}{c}\text { The dimension of the } \\
\text { grey area as \% GDP }\end{array}$ \\
\hline Poland & 13.8 & 16.67 \\
\hline Portugal & 10.8 & 17.82 \\
\hline Romania & 16.5 & 22.94 \\
\hline Pearson correlation coefficient & -0.60 \\
\hline P-value & 0.02 \\
\hline
\end{tabular}

Source: [Kukk et al., 2019; Medina, Schneider, 2018].

Another explanation of the observed relationship may be possible owing to the analysis of the relations between the index quantifying the friendliness of the state's tax policy for economic operators and the scale of income concealment (table 6). The conducted research shows that a more lenient position taken by the state towards taxpayers encourages them to reduce tax incomes. Therefore, it could be said that the state's mild tax policy may discourage taxpayers from operating in an illegal or unregistered way but leaves some scope for tax fraud.

TABLE 6

\section{The scale of income concealment by self-employed workers versus the value of Ease of Paying Taxes index}

\begin{tabular}{|l|c|c|}
\hline \multicolumn{1}{|c|}{ Country } & $\begin{array}{c}\text { The scale of income concealment } \\
\text { by self-employed workers in \% }\end{array}$ & $\begin{array}{c}\text { The value of Ease } \\
\text { of Paying Taxes index }\end{array}$ \\
\hline Bulgaria & 8.6 & 72.3 \\
\hline Cyprus & 9.1 & 85.5 \\
\hline Czech Republic & 21.9 & 81.4 \\
\hline Estonia & 22 & 89.9 \\
\hline Greece & 13.9 & 77.1 \\
\hline Spain & 13.5 & 84.7 \\
\hline Croatia & 16.8 & 81.8 \\
\hline Hungary & 24 & 80.6 \\
\hline Ireland & 30.1 & 94.6 \\
\hline Lithuania & 25.5 & 88.8 \\
\hline Latvia & 35 & 89 \\
\hline Poland & 13.8 & 76.4 \\
\hline Portugal & 10.8 & 83.7 \\
\hline Romania & 16.5 & 85.2 \\
\hline Pearson correlation coefficient & & 0.65 \\
\hline p-value & & 0.01 \\
\hline
\end{tabular}

Source: own elaboration based on: [Kukk et al., 2019; www 5]. 


\section{Conclusions}

Rather surprising the results of the conducted analyses may be explained in two different ways. The first explanation may question the quality of the data used here, especially as regards to the estimates of the phenomenon of income concealment. While the methodology used by Kukk et al. is one of the most recognisable ones, the quality of results always depends on the quality of the data being utilised. The weakness of this methodology may lie in the assumption that self-employed respondents completing the questionnaires concerning the amount of their incomes provide false information (similar to the data in tax declarations), but remain honest when they specify the level of their own consumption. Another drawback of the conducted research is the fact that it was based on a very small sample, owing to which the spreading of the results on the entire collection of countries is rather doubtful.

Another possible explanation of the results obtained may be based on the assumption that the results are correct. This would be synonymous with the existence of interchangeability between the components of grey area. The reduction of income by self-employed workers in such perspective may be considered as the consequence of the inclusion to the legal business transactions of entities that would be outside it in the conditions of a restrictive tax policy.

\section{References}

Alm J., Embaye A., 2013. Using Dynamic Panel Methods to Estimate Shadow Economies Around the World, 1984-2006, "Public Finance Review", vol. 41(5), pp. 510-543, DOI: $10.1177 / 1091142113482353$.

Artavanis N., Morse A., Tsoutsoura M., 2016, Measuring Income Tax Evasion Using Bank Credit: Evidence from Greece, "The Quarterly Journal of Economics", vol. 131(2), s. 739-798, DOI: 10.1093/qje/qjw009.

Blau D.M., 1987, A Time-Series Analysis of Self-Employment in the United States, "Journal of Political Economy", vol. 95(3), pp. 445-467.

Bruce D., 2000, Effects of the United States Tax System on Transitions into Self-Employment, "Labour Economics", vol. 7(5), pp. 545-574, DOI: 10.1016/S0927-5371(00)000 13-0.

Del'Anno R., 2003, Estimating the shadow economy in Italy: A structural equation approach. Discussion Paper, Department of Economics and Statistics, University of Salerno, Salerno.

Dhami S., Al-Nowaihi A., 2007, Why do people pay taxes? Prospect theory versus expected utility theory, "Journal of Economic Behavior and Organization", vol. 64(1), pp. 171, DOI: 10.1016/j.jebo.2006.08.006.

Frey B.S., Feld L., 2002, Deterrence and morale in taxation: An empirical analysis, "CESifo Working paper", No. 760. 
Hazans M., 2011, Informal Workers Across Europe: Evidence from 30 Countries, "Discussion Paper", No. 5871, pp. 1-44.

Jacobsen Kleven H., Knudsen M.B., Thustrup Kreiner C., Pedersen S., Saezi E., 2011, Unwilling or Unable to Cheat? Evidence from a Tax Audit Experiment in Denmark. “Econometrica”, vol. 79(3), pp. 651-692, DOI: 10.3982/ECTA9113.

Kukk M., Paulus A., Staehr K., 2019, Cheating in Europe: Underreporting of SelfEmployment Income in Comparative Perspective, "International Tax and Public Finance", vol. 27, pp. 363-390, DOI: 10.1007/s10797-019-09562-9.

Łapiński K., Peterlik M., Wyżnikiewicz B., 2014, Szara strefa w polskiej gospodarce, Instytut Badań nad Gospodarką Rynkowa, Warszawa.

Medina L., Schneider F., 2018, Shadow Economies Around the World: What Did We Learn Over the Last 20 Years?, "IMF Working Paper", No. 18/17, pp. 1-76.

Parker S., 1996, A Time Series Model of Self-Employment under Uncertainty, "Economica", vol. 63(251), pp. 459-475.

Pissarides C.A., Weber G., 1989, An expenditure-based estimate of Britain's black economy, "Journal of Public Economics", vol. 39(1), pp. 17-32, DOI: 10.1016/00472727(89)90052-2.

Robson M.T., Wren C., 1999, Marginal and Average Tax Rates and the Incentive for SelfEmployment, "Southern Economic Journal", vol. 65(4), pp. 757-773, DOI: $10.2307 / 1061274$.

Sandomo A., 2005, The Theory of Tax Evasion: A Retrospective View, "National Tax Journal", vol. 58(4), pp. 643-663.

Schneider F., Klinglmair R., 2004, Shadow Economies around the World: What Do We Know?, "IZA Discussion Paper", vol. 1043, pp. 1-60.

Schuetze H., 2000, Taxes, Economic Conditions and Recent Trends in Male Self-Employment: A Canada-US Comparison, "Labour Economics", vol. 7(5), pp. 507-544.

Smith K.W., Stalans L.J., 1991, Encouraging Tax Compliance with Positive Incentives: A Conceptual Framework and Research Directions, "Law and Policy", vol.13(1), pp. 35-53.

Srinivasan T., 1973, Tax evasion: A model, "Journal of Public Economics", vol. 2(4), pp. 339-346, DOI: 10.1016/0047-2727(73)90024-8.

Tafenau E., Herwartz H., Schneider F., 2010, Regional Estimates of the Shadow Economy in Europe, 'International Economic Journal", vol. 24(4), pp. 629-636, DOI: 10.1080/10168737.2010.526010.

www 1, http://www.oecd.org/ctp/glossaryoftaxterms.htm [date of entry: 23.03.2020]. www 2, https://ec.europa.eu/eurostat/databrowser/view/sdg_08_10/default/table

?lang=en [date of entry: 23.03.2020].

www 3, https://ec.europa.eu/eurostat/databrowser/view/tps00203/default/table? lang=en [date of entry: 23.03.2020].

www 4, https://data.oecd.org/emp/self-employment-rate.htm [date of entry: 23.03. 2020].

www 5, https://www.pwc.com/gx/en/services/tax/publications/paying-taxes-2020

/explorer-tool.html [date of entry: 23.03.2020]. 